\title{
EFEKTIVITAS PENGGUNAAN MINDFULNESS APP BERBASIS SMARTPHONE UNTUK MENGURANGI STRES
}

\author{
${ }^{1}$ Eli Saripah, ${ }^{2}$ Hanny Handiyani \\ Fakultas Ilmu Keperawatan Universitas Indonesia \\ 1ellysdiamondsnow@gmail.com, ${ }^{2}$ honey@ui.ac.id
}

\begin{abstract}
Abstrak
Stres merupakan penyebab banyak penyakit di masyarakat modern. Pengurangan stres berbasis mindfulness merupakan salah satu cara mengurangi tingkat stres yang dialami oleh seseorang. Karena meningkatnya permintaan akan layanan kesehatan preventif terhadap stres, maka penting untuk mengembangkan strategi dalam mengelola stres pada smarthphone. Mindfulness dapat diintegrasikan ke dalam praktik terapi untuk mengurangi stres. Pelatihan berbasis bukti mampu mengurangi stres menggunakan mindfulness App pada smarthphone. Kajian ini betujuan untuk meninjau dan menganalisis secara sistematis mengenai efektivitas penggunaan mindfulness App untuk mengatasi stres. Metode kajian ini dirancang sebagai literature review dengan mengumpulkan literatur yang didapatkan dari database Scopus, ProQuest, dan Wiley Online Library. Uji coba ini menunjukkan bahwa meditasi mindfulness terpandu singkat yang disampaikan melalui smartphone dan dipraktikkan beberapa kali per minggu dapat meningkatkan hasil yang terkait dengan pengurangan stres dan kesejahteraan kerja, dengan efek yang berpotensi bertahan lama.
\end{abstract}

Kata Kunci: meditasi, mindfulness, smarthphone, stres

\section{Pendahuluan}

Stres telah menjadi penyebab yang signifikan karena berbagai penyakit di masyarakat modern (Can, Arnrich, \& Ersoy, 2019). Stres psikososial kronis berkontribusi terhadap kondisi kesehatan, dengan demikian tantangan klinis yang berkembang dan meresap ke sistem perawatan kesehatan saat ini. Dampak dari stres juga cukup tinggi dan salah satu cara untuk mengatasinya adalah dengan menggunakan teknologi terkini. Teknologi mHealth sebagai perkembangan paling inovatif di bidang perawatan kesehatan dan kesehatan masyarakat. Hal ini memberikan peluang besar untuk peningkatan promosi kesehatan, pencegahan penyakit dan perawatan medis (Duplaga \& Tubek, 2018).
Aplikasi pada smarthphone memiliki potensi sebagai manajemen stres yang mudah diakses dan mudah beradaptasi di masyarakat. Alat yang dapat melengkapi perawatan berbasis klinik dan mungkin dapat mengurangi beban stress yang dirasakan. Saat ini banyak orang dewasa memiliki smartphone, dan tingkat kepemilikan adalah tertinggi dalam populasi dan memungkinkan akan mengalami tingginya tingkat stres kronis dan hambatan dalam mengakses preventif layanan kesehatan. Mindfulness app yang terdapat pada smartphone membantu dalam proses mengurangi stres. Aplikasi dengan penelitian intervensi berbasis bukti ini menunjukkan bahwa mindfulness terpandu singkat yang disampaikan melalui smartphone dan dipraktikkan beberapa kali per minggu dapat meningkatkan hasil yang terkait dengan pengurangan stres dan 
JURNAL ILMU KESEHATAN BHAKTI HUSADA:

HeAlth SCIENCES JournAL, Vol. 10 No. 02, DeSember 2019

DOI: 10.34305/JIKBH.V10I2.97

kesejahteraan kerja, dengan efek yang berpotensi bertahan lama.

Penelitian sebelumnya menunjukkan

bahwa pelatihan mindfulness dapat meningkatkan aspek kesejahteraan psikososial. Sementara mindfulness secara tradisional diajarkan secara langsung, dan konsumen semakin beralih ke aplikasi smartphone berbasis mindfulness app sebagai media alternatif untuk pelatihan (Champion, Economides, \& Chandler, 2018)

Fakultas dan peserta pelatihan membutuhkan keterampilan klinis, pengetahuan, dan sikap untuk memastikan perawatan berkualitas menggunakan teknologi. Staf pengajar klinis mengajar, mengawasi, dan menjadi panutan bagi peserta pelatihan dan anggota tim interprofesional. Kompetensi kesehatan berbasis sistem informasi manajemen kesehatan dan aplikasi dapat ditempatkan dalam domain tonggak pendidikan lulusan keperawatan. Kompetensi ini memiliki

analisis untuk peningkatan program preventif pada masyarakat seperti dukungan keputusan klinis, pemilihan teknologi, dan manajemen aliran informasi lintas platform elektronik. Sistem kesehatan harus mengintegrasikan tatap muka dan perawatan berbasis teknologi, sambil mempertahankan hubungan terapeutik (Archuleta, Jennings, \& Cunliff, 2019)

\section{Metode}

Kajian ini dirancang dengan menggunakan desain literature review dengan sumber literatur yang didapatkan dari database Scopus, ProQuest, dan Wiley Online Library dengan mesin pencari lib.ui.ac.id. Adapun kata kunci yang digunakan dalam proses pencarian sumber literatur adalah meditasi, mindfulness, smarthphone, stres. dipublikasikan minimal 4 tahun terakhir (2016-2019). Adapun alur pemilihannya dapat dilihat pada gambar berikut:

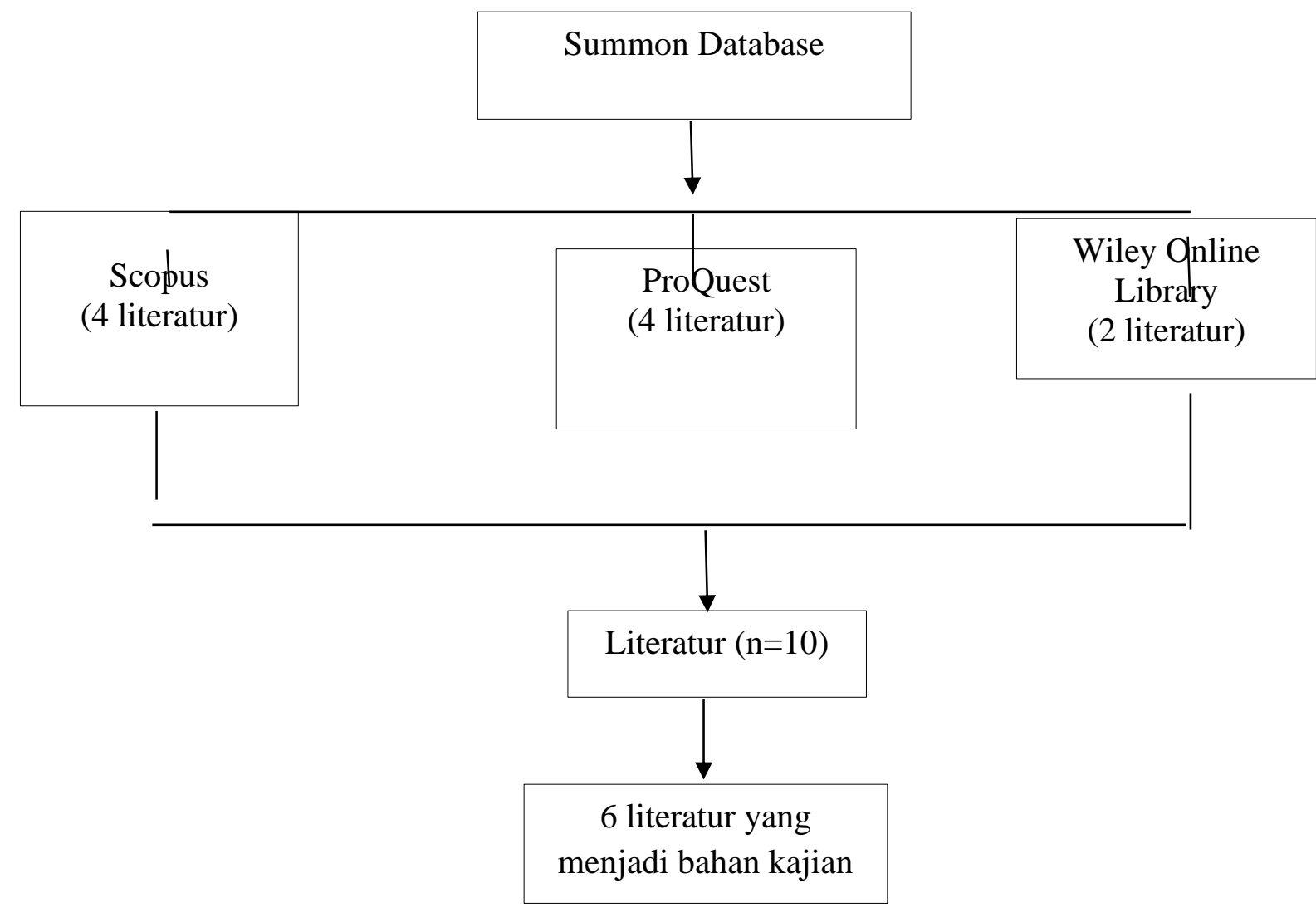

Gambar 1: Pemilihan Studi 
JURNAL ILMU KESEHATAN BHAKTI HUSADA:

HEALTH SCIENCES JOURNAL, Vol. 10 No. 02, DeSEMBER 2019

DOI: $10.34305 / J I K B H . V 10 I 2.97$
Ciptaan disebarluaskan di bawah

Lisensi Creative Commons Atribusi-

NonKomersial-BerbagiSerupa 4.0

Internasional.

\section{Hasil dan Pembahasan}

Berdasarkan hasil analisa dari keenam literatur yang direview didapatkan bahwa dari masing-masing literatur menunjukkan keragaman modifikasi terutama pada efektivitas penggunaan mindfulness app dalam menangani stres dimana temuan lebih lanjut menunjukkan bahwa pendekatan intervensi yang komprehensif dapat membedakan efektivitas aplikasi tradisional dengan strategi berbasis bukti menggunakan aplikasi smarthphone. Intervensi berbasis seluler ini telah terbukti efektif dalam mengurangi stres pada karyawan dalam jangka panjang. Intervensi manajemen stres berbasis internet harus dilanjutkan sebagai alternatif yang berharga pengganti intervensi tatap muka.

Kajian pada studi yang dilakukan oleh Mikolasek, Berg, Witt, \& Barth, (2018) menunjukkan bahwa intervensi e-Health berdasarkan mindfulness dan relaksasi dapat memiliki efek positif pada hasil kesehatan. Oleh karena itu, intervensi tersebut dapat menjadi tambahan yang berguna untuk perawatan medis standar. Sejumlah besar aplikasi smarthphone bertujuan untuk meningkatkan kesehatan pengguna dan mencari tahu tentang aplikasi kesehatan yang diperlukan. Salah satu keuntungan paling penting dari e-Health adalah aksesibilitasnya yang tinggi karena akses yang sedia internet oleh mayoritas orang seluruh dunia, yang juga memungkinkan bagi orang-orang yang lokasinya jauh dan kurang dalam akses untuk mobilitas.

Studi yang dilakukan oleh Champion, Economides, \& Chandler, (2018) menunjukkan bahwa hasil uji coba terkontrol secara acak terjadi peningkatan dalam hasil psikososial yang dapat dicapai dengan biaya rendah melalui keterlibatan jangka pendek dengan aplikasi mindfulness berbasis smartphone, dan harus ditindaklanjuti dengan studi yang lebih substantif. Aplikasi iPhone berbasis skor tertinggi berdasarkan sistem aplikasi seluler, dan sebelumnya telah terbukti meningkatkan belas kasih dan kesejahteraan.

Studi yang dilakukan oleh Bostock, Crosswell, Prather, \& Steptoe, (2019) menunjukkan efek positif berkelanjutan dalam kelompok intervensi untuk kesejahteraan dan mengurangi tekanan pekerjaan pada penilaian tindak lanjut selama 16 minggu. Uji coba ini menunjukkan bahwa meditasi mindfulness terpandu dan singkat yang disampaikan melalui smartphone dan dipraktikkan beberapa kali per minggu dapat meningkatkan hasil yang terkait dengan stres dan kesejahteraan kerja, serta efek yang berpotensi bertahan lama.

Studi yang dilakukan oleh Vacca, (2018) perangkat seluler dapat memberikan peluang baru untuk mendukung praktik mindfulness yang tempatnya dekat dengan kehidupan sehari-hari. Pendekatan mindfulness baru dieksplorasi melalui desain aplikasi seluler. pendekatan ini dengan meditasi kesadaran berbasis audio tradisional dan kontrol pengembara pikiran, selama periode satu minggu. Studi ini menunjukkan kelayakan untuk pendekatan mindfulness dengan smartphone yang ada untuk menginduksi keadaan mindfulness. Namun, aspek fenomenologis dari pendekatan ini menyarankan untuk keduaduanya dilakukan untuk meningkatkan penggunaan smartphone.

Studi yang dilakukan oleh Rosen, Paniagua, Kazanis, Jones, \& Potter, (2018) mengenai pemanfaatan aplikasi, dan penyelesaian studi dilaporkan sebagai tujuan kelayakan. Temuan menunjukkan aplikasi seluler yang tersedia secara komersial dapat memberikan beberapa manfaat bagi wanita yang ingin meningkatkan kualitas hidup mereka. 
JURNAL ILMU KESEHATAN BHAKTI HUSADA:

HeALTH SCIENCES JOURNAL, Vol. 10 No. 02, DeSEMBER 2019 DOI: $10.34305 / J I K B H . V 10 I 2.97$

Studi yang dilakukan oleh (Heber, Lehr, Ebert, Berking, \& Riper, 2016) mengenai Intervensi berbasis web untuk mengatasi stress harus lebih jauh dievaluasi karena intervensi tersebut berpotensi untuk meningkatkan kesehatan mental individu dalam skala besar

Ringkasan mengenai review dari studi efektivitas penggunaan mindfulness berbasis smartphone yang dimasukkan sebagai literatur kajian di sini dapat dilihat pada tabel 1 yang telah dilampirkan pada akhir halaman kajian literatur ini.

\section{Kesimpulan dan Rekomendasi}

Keenam literatur yang diulas dalam kajian literatur ini merupakan hasil studi yang secara keseluruhan menunjukkan gambaran efektivitas dari penggunaan mindfulness app berbasis smartphone. Pemberian intervensi mindfulness app berbasis smartphone ini telah terbukti efektif dalam mengurangi stres. Uji coba ini menunjukkan bahwa meditasi mindfulness terpandu singkat yang disampaikan melalui smartphone dan dipraktikkan beberapa kali per minggu dapat meningkatkan hasil yang terkait dengan pengurangan stres dan kesejahteraan kerja.

Kajian literatur ini memberikan bukti yang mendukung keefektifan smartphone dalam mengatasi masalah stress. Namun demikian, masih dibutuhkan studi lebih lanjut terkait efektivitas penggunaan aplikasi ini di Indonesia, agar stress yang terjadi di Indonesia juga dapat teratasi melalui pendekatan berbasis smartphone.

\section{Daftar Pustaka}

Archuleta, K., Jennings, C. T., \& Cunliff, E. (2019). Mindfulness at Metropolitan Universities. New Directions for Adult and Continuing Education, 2019(161), 33-43.

https://doi.org/10.1002/ace.20309

Bostock, S., Crosswell, A. D., Prather, A. A., $\&$ Steptoe, A. (2019). Mindfulness on- the-go: Effects of a mindfulness meditation app on work stress and wellbeing. Journal of Occupational Health Psychology, 24(1), 127-138. https://doi.org/10.1037/ocp0000118

Can, Y. S., Arnrich, B., \& Ersoy, C. (2019). Stress detection in daily life scenarios using smart phones and wearable sensors: A survey. Journal of Biomedical Informatics, 92(August 2018), 103139. https://doi.org/10.1016/j.jbi.2019.1031 39

Champion, L., Economides, M., \& Chandler, C. (2018a). The efficacy of a brief app-based mindfulness intervention on psychosocial outcomes in healthy adults: A pilot randomised controlled trial. PLoS ONE, 13(12), 121.

https://doi.org/10.1371/journal.pone.0 209482

Champion, L., Economides, M., \& Chandler, C. (2018b). The efficacy of a brief app-based mindfulness intervention on psychosocial outcomes in healthy adults: A pilot randomised controlled trial. PLOS ONE, 13(12), 121.

https://doi.org/10.1371/journal.pone.0 209482

Duplaga, M., \& Tubek, A. (2018). mHealth - areas of application and the effectiveness of interventions. Zdrowie Publiczne $i$ Zarzadzanie, 16(3), 155166.

https://doi.org/10.4467/20842627oz.18 .018 .10431

Heber, E., Lehr, D., Ebert, D. D., Berking, M., \& Riper, H. (2016). Web-Based and Mobile Stress Management Intervention for Employees: A Randomized Controlled Trial. Journal of Medical Internet Research, 18(1), e21. https://doi.org/10.2196/jmir.5112

Mikolasek, M., Berg, J., Witt, C. M., \& Barth, J. (2018). Effectiveness of Mindfulness- and Relaxation-Based eHealth Interventions for Patients with 
Medical Conditions: a Systematic Review and Synthesis. International Journal of Behavioral Medicine, 25(1), 1-16. https://doi.org/10.1007/s12529017-9679-7

Rosen, K. D., Paniagua, S. M., Kazanis, W., Jones, S., \& Potter, J. S. (2018). Quality of life among women diagnosed with breast Cancer: A randomized waitlist controlled trial of commercially available mobile app-delivered mindfulness training. PsychoOncology, 27(8), 2023-2030. https://doi.org/10.1002/pon.4764

Vacca, R. (2018). Promises and pitfalls of computer-supported mindfulness: Exploring a situated mobile approach. Computers, $7(1)$. https://doi.org/10.3390/computers7010 002 